\title{
ENO2 wt Allele
}

National Cancer Institute

\section{Source}

National Cancer Institute. ENO2 wt Allele. NCI Thesaurus. Code C62213.

Human ENO2 wild-type allele is located within 12p13 and is approximately $9 \mathrm{~kb}$ in length.

This allele, which encodes gamma-enolase protein, is involved in glycolysis. The ENO2

gene is overexpressed in certain cancers such as neuroendocrine carcinomas and small cell lung cancer. 